\title{
Endogenisation or enclave formation? The development of the Ethiopian cut flower industry*
}

\author{
Ayelech Tiruwha Melese \\ Dir Foundation, Nieuwpoortstraat 9o-D, I055RZ Amsterdam, \\ The Netherlands \\ Email: eyeyou94@gmail.com \\ and \\ A.H.J. (BERT) HELMSING \\ Institute of Social Studies, P.O. Box 29776, 2502 LT The Hague, \\ The Netherlands \\ Email: helmsing@iss.nl
}

\begin{abstract}
A B S T R A C T
This paper examines the evolution of the Ethiopian cut flower industry, illustrating how rapidly a potential comparative advantage can be realised. But the question is to what extent a country benefits from this in the long run, if foreign direct investment is the principal driving force. Will the new industry become an enclave, or will it be accompanied by a process of building local capabilities, a process which we denominate endogenisation? A value chain framework is used to analyse the industry and to develop a number of indicators on the development direction. The cut flower industry in Ethiopia is characterised by a dominant role of Dutch foreign investors, Dutch trade auctions which dominate the export trade, and the Dutch development cooperation which plays an important role in the development of the sector. This raises the question to what extent this triple role of the Dutch contributes to endogenisation or to enclave formation.
\end{abstract}

\footnotetext{
* The authors would like to acknowledge the useful comments from two anonymous referees and from the editor of JMAS.
} 
We conclude that endogenisation is a two-way process. It depends both on the degree to which FDI has an interest to draw on domestic firms, enter into relationships and share technologies; and on the interest and ability of domestic firms to take up such opportunities, and on the creation of supporting institutions and infrastructures to make this take-up possible. The latter rests largely with government. Endogenisation is taking place to some extent and at a very incipient stage. Dutch FDI has little direct interest to share technologies, but there is joint collective action on non-core activities, notably transport, which constitutes the largest item in the total cost. Dutch cooperative flower auctions are an open and vital trade channel giving Ethiopian flower growers access to international markets. The Ethiopian government has promoted the industry, making available land and low cost finance; and with the assistance of Dutch bilateral cooperation it is creating trade standards and supporting knowledge institutions to train skilled staff. The main challenge is Ethiopian entrepreneurship: many are attracted by the high growth and profitability of the industry and can run a business in Ethiopia, but lack the technical competence to meet growing competition in the industry.

\section{N T R O D U C T I O N}

The role of foreign direct investment (FDI) in economic development is a controversial one. Increasingly, a view is emerging that the developmental significance of FDI depends both on the type and behaviour of FDI, and also on the capabilities of local firms in the recipient country (Lall \& Narula 2004). Especially in the case of poor countries, there is often a paradox: there is a great need for investment and innovation, employment creation and export, but in the absence of local capabilities, FDI in a particular sector is likely to become an enclave-generating direct employment but with little positive and sustainable effects spilling over onto domestic firms. A central question is therefore to what extent the expansion of FDI in a sector is accompanied by a process of building local capabilities. This we call endogenisation, defined as the progressive development of local capabilities and local control of a new export base that has initially been shaped by external factors and forces.

In the last five years, the floriculture sector of Ethiopia has been expanding rapidly. Many domestic and foreign investors have entered it. The Dutch in particular participate vigorously in several parts of the cut flower value chain: (I) in production, Dutch growers were responsible in 2007 for $37 \%$ of the total production for export (478 million stems - figures which underestimate their role, as they exclude the exported output of joint ventures with Ethiopian growers; (2) in trade, two thirds of the total Ethiopian export went in the same year to the Dutch market via its two auctions, VBA and FloraHolland; and, last but not least, (3) Dutch 
development cooperation plays a critical role in the establishment of key institutions for Ethiopian flower industry. Since Ethiopia is one of the world's poorest countries, and has in the past had low participation in global FDI, this is an interesting case through which to examine the extent of endogenisation.

This paper has three aims: (a) to examine the evolution of the Ethiopian cut flower industry; (b) to examine the degree to which this development moves in the direction of endogenisation or enclave formation; and (c) to discuss the triple role of Dutch actors in this process. Section 2 provides a brief discussion of the central analytical concepts. Section 3 examines the evolution of the Ethiopian cut flower industry, and Section 4 looks at different segments of the value chain and the position of Ethiopian and Dutch actors therein. Section 5 briefly recounts the developmental impact of this new industry, while Section 6 draws conclusions about the development direction, and assesses the triple role of the Dutch.

FDI, ENDOGENISATION OR ENGLAVE FORMATION:A VALUE

CHA I N P E R S P E C T I V E

The value chain framework provides a helpful tool through which to examine the effects of FDI in a country, and the direction of development in the industry concerned. The value or production chain is 'a transactionally linked sequence of functions in which each stage adds value to the process of production of goods and services' (Dicken 2003: 7). The framework shows how each functional element in the production sequence involves transactions, and depends on technological and other inputs, including production technology and related research and development, and also transport logistics and communication processes. These may be provided by firms themselves or by other private and public actors. A production chain is embedded in a financial system that finances investments and recurrent transactions. Firms coordinate these production and transaction sequences internally or with other firms in various ways. In addition to both foreign and domestic firms active in particular value adding activities, institutions and institutional arrangements surround and support the functioning of the chain. These are developed by a variety of actors, including technology, human resource development (HRD), research and development (R\&D), transport and communication, the system that finances transactions, and institutions concerned with coordination, regulation and control of the chain. 
Regulation helps to reduce coordination problems and may be undertaken by firms themselves, their associations or by government. Value chain framework shows the complexity of a particular productiontransaction sequence (functional interdependence). How various actors handle this complexity is the central issue of value chain governance. Kaplinsky (2000) identified three aspects of governance, namely legislative, judicial and executive governance, which may be exercised by public or private actors within or external to the chain. Last but not least, geography plays a role in value chain analysis, not only because of the spatial extension of chains but also because of economic differentiation between production and transaction locations.

Many studies focus on private actors internal to the chain, especially the lead firms and their role in chain governance. Producer-driven and buyer-driven chains are characterised by a lead firm in production and in trading respectively (Gereffi I994; Gereffi et al. 200I). Gibbon (200I) identified a so-called trader-driven chain that often applies to agricultural commodities. Dolan and Humphrey (2000) illustrate the power of retailers in the way they influence and shape the governance of fresh vegetables chains from Africa to UK supermarkets.

Other actors who play a role in the development of particular value chains are governments and NGOs. Government policy plays an important role in the financial system in which a chain is embedded, especially through the provision of particular credit lines or guarantees, and through banking and FDI regulation. Furthermore, governments are often directly or indirectly responsible for the provision of transport and communication infrastructure. Through education and R\&D policies, they can stimulate research in technologies and human resources development relevant to a particular industry. Through industrial policies, governments can provide important complementary support. Last but not least, public regulation of international trade and environmental standards has a direct bearing on the development of new export chains. In a similar vein, NGOs can play a role either through voluntary regulation or through capacity building of other actors in the chain (e.g. small producer entrepreneurs). In the next section, we use the value chain framework to describe the different dimensions of the Ethiopian cut flower chain, identify its value adding activities, and examine the participation of different actors in it.

The theory of dynamic comparative advantage is a useful starting point for a discussion of the notion of endogenisation. This theory maintains that comparative advantages of a country are not simply determined by its particular endowments or characteristics, but need to be created through 
learning (and renewed, one should add, as markets increasingly globalise). A country may have a particular potential, but needs to realise this through purposeful action. Seen from a value chain perspective of a new industry, it is quite likely that the required embedding - the supporting system of science and technology services and of human resources development needed for the industry - may not exist. Similarly the country concerned may lack the necessary transport and communication infrastructure in the most attractive production locations. The regulation and institutional arrangements needed to coordinate and control certain aspects of the new production and transaction sequence may have to be developed. Particular inputs needed in the production-transaction sequence may have to be imported. Export markets have to be found. Thus, for the realisation of the potential comparative advantages, there are considerable upfront development costs, and domestic firms may have neither the capability to enter a new industry on their own, nor the capacity to finance these upfront costs. Knowledge gaps and risks may be too large. Foreign direct investment is therefore often relied on to exploit the potential comparative advantages. The central question however is to what extent FDI is helpful in developing capabilities of domestic firms.

Poh (2006) has recently raised this question using a value chain framework. To what extent does FDI contribute to upgrading in the host country, defined at micro level as a shift from assembly to own-brand manufacturing, and at macro level from a resource-based production structure to a capital intensive hi-tech one? Poh defines endogenisation as the creation of new factors of production in the host country resulting from exogenous factors brought by TNCs (ibid.). He emphasises that this goes beyond the ability to produce to the requirements of foreign company headquarters (which would amount to no more than 'transplanting'), but involves a continuous process of learning, bargaining and simultaneously applying knowledge in order to build up the local capabilities for technological and organisational innovation, which in the end would lead to the creation of own factors of production, and to industrial upgrading of products and technology. Endogenisation is a complex process, requiring substantial efforts by local firms, as well as the support of sectoral and other institutions, which themselves may have to be created first as part of the very same process of endogenisation. Thus, endogenisation does not only emanate from FDI, but also requires receptive domestic firms, and needs to be construed or co-produced by a pro-active government policy.

Poh also developed some indicators to measure progress in endogenisation, namely: (a) FDI-induced local physical capital, (b) human 
capital, and (c) knowledge capital. Due to the difficulty of measuring these indicators directly, he proposed several proxies. Proxies for the first indicator are change in number of domestic firms relative to the number of foreign firms active in the industry; change over the years in the percentage of local content; and change in total number of domestic suppliers relative to foreign subsidiaries. Proxies for the second indicator are qualitative descriptions of domestic entrepreneurs; acquisition of managerial expertise; and the number of engineers, technicians and workers trained by FDI. Proxies for the third indicators may include the quality of managerial expertise, production skills, design capability and development of R\&D facilities (ibid.: 57-63).

It is also important to recognise that not only FDI but also international development cooperation and international NGOs can assist in endogenisation, especially as regards the embedding of new value chains. International development cooperation can facilitate the financing of chains and their associated supporting institutions and infrastructures. Moreover, it can help speed up the learning process by facilitating technical assistance and capacity building of firms (through business development services, BDS), and of supporting and regulatory institutions. NGOs can play a role in capacity building of small producers and be active in voluntary regulation concerning new export chains.

Helmsing $(2005,2007)$ defined endogenisation as the progressive development of local capacities and local control over an export base that was previously shaped by external factors and forces. The element of local control is important to counterbalance the power asymmetries that may exist within the global chain. Since it is an on-going cumulative process, endogenisation has its own phases, though these are not necessarily sharply separated but may overlap. Initially, endogenisation is concerned with expanding the base of local producers, by increasing the participation of local firms in a sector introduced and given shape by external factors (like FDI). The potential entry of local firms would presumably reveal itself in high potential profit rates and the success of early starters. It may be necessary to create financial access for their entry and to facilitate their acquisition of industry-specific competencies. This can be done through special financial arrangements from internal and external sources, and by creating local knowledge centres (universities, vocational schools, testing and experimental stations). Endogenisation enters a further stage when the number of firms is large enough to create conditions for cluster development. Initially cooperation and joint actions may be promoted on non-core activities (e.g. jointly buying inputs). An important milestone would be the creation of associations and associative enterprises 
to facilitate and coordinate interaction among firms, as well as between firms and knowledge centres and supporting institutions (government and others). Endogenisation reaches a mature level when expanding R\&D for continuous upgrading and innovation on diversified products, marketing and branding. Government support in terms of an enabling role and the creation of specialised infrastructures plays a role during the entire process.

The concept of enclave has been used more widely. Here we use it with regard to the economic situation and in relation to the effect of FDI and the position of domestic firms in relation to FDI. Enclave formation in this setting is characterised by a specific sector controlled by external firms (FDI), and highly dependent on imported capital and technology which are neither compatible with local firms' capacity nor connected to the rest of the economy (Görg \& Strobl 2005; UNCTAD 2005). The number of domestic firms operating in an enclave thus remains small, and the main actors in the enclave rarely create backward and forward linkages, so that it is 'a mere diffusion of different branches of multinational corporations among many different countries throughout the international economy' (Weisskoff \& Wolff I977; see also Hojman I983). The host country may suffer more from the outflow of resources than it gains from FDI inflow. In its zeal to attract FDI and create employment, government policy (e.g. through export processing zones) may, intentionally or not, stimulate enclave formation by the type of incentives provided (no import duties, no VAT on exports, thus making local procurement unattractive). This becomes even worse if domestic firms cannot apply for these incentives.

In general, enclave formation refers to the growing exclusion and loss of local control over the export base of a region or a country; it concerns an extractive process by external firms which have very low reinvestment rates; and benefits and development of the economy are usually exclusive to FDI, with little room for linkages and knowledge spillover and learning by local firms (Helmsing 2005).

On the basis of the above notions we are able to formulate a set of indicators to use in our study of the Ethiopian cut flower value chain. Table I presents the indicators in three blocks: production, trading in export markets, and sectoral development. Production indicators refer to the relative position of domestic firms; the attitude and competencies of domestic entrepreneurs; the extent of cooperation between domestic firms and FDI active in the chain in the form of joint action; and transfer of knowledge between FDI and domestic firms. Indicators can also be performance-oriented, such as the production performance of 
TABLE I

Indicators for endogenisation and enclave formation

\begin{tabular}{|c|c|c|c|}
\hline & Indicator & Endogenisation & Enclave formation \\
\hline \multirow[t]{9}{*}{ Production } & Domestic firms' presence relative to FDI & High or growing & Low and stagnant \\
\hline & Competencies and attitudes of domestic & Strono and gualified innovative & Weak and low gumalifications \\
\hline & Cooperation between domestic firms and FDI & Occurs & Absent \\
\hline & $\begin{array}{l}\text { Transfer of knowledge and best practices from } \\
\text { FDI to domestic firms: }\end{array}$ & Occurs & Absent \\
\hline & - Directly, e.g. through joint ventures & & \\
\hline & $\begin{array}{l}\text { - Indirectly, mobility of management and/or } \\
\text { skilled labour }\end{array}$ & & \\
\hline & Performance of domestic firms relative to FDI & Closing the gap & Large gap \\
\hline & Forward linkage & Present & Absent \\
\hline & Backward linkages & Present & Absent \\
\hline \multirow[t]{2}{*}{ Trading } & $\begin{array}{l}\text { FDI control over trading/traders/trade } \\
\text { infrastructure }\end{array}$ & Absent & Present \\
\hline & $\begin{array}{l}\text { Market segmentation and/or discrimination of } \\
\text { Domestic firms by international traders }\end{array}$ & Absent & Present \\
\hline \multicolumn{4}{|l|}{ Sectoral development } \\
\hline Host government policy & Fiscal incentives and financial instruments & $\begin{array}{l}\text { Equal for FDI and domestic or in } \\
\text { favour of latter }\end{array}$ & Exclusively for FDI \\
\hline International cooperation & $\begin{array}{l}\text { Benefit of sector development and of sector } \\
\text { institutions }\end{array}$ & $\begin{array}{l}\text { Equal for all or only for domestic } \\
\text { firms }\end{array}$ & Exclusively in favour of FDI \\
\hline
\end{tabular}


domestic firms relative to FDI as shown by productivity, price and quality, and the extent of forward and backward linkages to FDI by domestic firms. In trading, an important indicator is the existence of an open trade channel for domestic and FDI alike; FDI control over international trade and the existence of market segmentation and/or discrimination of domestic firms by international traders is likely to reduce the scope for endogenisation. Sectoral development denotes the creation of the regulatory and supporting institutions by government policy, directly or with the assistance of international development cooperation. The key criterion is the degree to which these developments are exclusively focussed on FDI or are also open to or exclusively benefiting domestic firms. As both endogenisation and enclave formation refer to a process over time, the indicators should denote a change over time. Although the indicators in Table I are static, in practice they are dynamic, indicating a process.

EVOLUTION OF THE FLORICULTURE INDUSTRY IN ETHIOPIA

Until very recently, Ethiopia was hardly known in the industry, which in most countries is dominated by roses. Competition is growing as producers from different parts of the world enter the industry. South American countries like Ecuador and Colombia are known for production of large-bud roses, while East African countries produce small-bud roses (Wijnands 2005). Cut flowers are becoming one of the main export items in eastern and other African countries such as Zimbabwe, Zambia, Uganda and Kenya. Kenya is the fifth largest exporter in the world (after The Netherlands, Colombia, Ecuador and Israel). All developing countries produce mainly for export. The EU, USA and Japan are the main destination markets. Due to market proximity, most South American flowers are exported to the USA, whereas Africa mainly caters for the EU market. Japan is supplied by The Netherlands and by some Asian and African countries (ibid.).

The Netherlands has a strong position in the global flower market, and is the hub for the EU cut flower trade, as the largest exporter as well as the third largest importer in the region. In 2005 The Netherlands' cut flower exports amounted to $€_{2.4}$ billion, and imports to $€_{4} 6_{5}$ million, mainly from developing countries (CBI 2006). Kenya supplied the largest share (36\%), followed by Ecuador (г \%) and Zimbabwe (6\%) (ibid.). Ethiopia only recently emerged with a large potential for production of small as well as large-bud roses. As a result it is rapidly taking a significant share in the Dutch imports. According to one Ethiopian flower trader interviewed in 
2007, Ethiopia's share is estimated at Io \% of the total volume traded at the VBA auction (about 4 billion stems).

The origin of the industry in Ethiopia can be traced back to the Derg regime, when summer flowers for export were grown on state farms. ${ }^{1}$ After the fall of the regime in I99I, two Ethiopian firms, Ethioflora and Meskel Flower, pioneered floriculture in Ethiopia, and have been exporting summer flowers for some time. In the mid nineties, Meskel Flower shifted its production to roses, due to high competition from Kenyan summer flower growers in export markets, exporting Ethiopian roses to the European market for the first time in 1997. Both companies and in particular Meskel Flower received substantial technical and financial support from the World Bank and from FMO (Finance for Development) from Holland. However, they faced an unfavourable investment climate, and had limited experience and knowledge about the business. Moreover, there was little support from government. The companies had difficulties acquiring sufficient and suitable land, purchasing necessary inputs, financing and transporting the flowers to the market. ${ }^{2}$

The first foreign investor, Golden Rose, arrived in 1999 from the United Kingdom and showed Ethiopia's potential to grow quality roses. Its success attracted additional domestic and foreign investors such as ENYI Rose and Summit (domestic firms), and Ethio-Dream (joint venture). According to a World Bank (2004) study, these four companies were the only rose exporters until the beginning of 2004. Since then, FDI has increased rapidly, especially from The Netherlands.

Currently, the floriculture of Ethiopia can be divided into three groups: roses under greenhouse, cuttings under greenhouse, ${ }^{3}$ and summer flowers. About $80 \%$ of the total production area is covered by roses, which are cultivated mostly on soil and in some cases on hydroponics

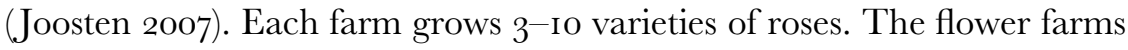
are mainly concentrated in the highlands, ranging from I,550 to 2,600 metres and within a $200 \mathrm{~km}$ radius from Addis Ababa where the international airport is located. Concentrations of farms are found in the vicinity of the towns of Holleta, Ziway, Sebeta, Debre Zeit and Addis Alem (see Table 2). In March 2006, 2,03 I hectares of land were allocated to investors for floriculture development, and by June 2007, $80 \mathrm{or} \cdot 6 \mathrm{hec}-$ tares were in production. ${ }^{4}$ As of June 2007, seventy companies were active in the industry and six companies were setting up operations. In the three years up to 2007, both export volume and earnings showed more than fivefold growth (see Table 3), and this made flowers the sixth largest export commodity of the country, after coffee, oilseeds, chat, leather and live animals (ENST 2006). 
TABLE 2

Location of cut flower farms

\begin{tabular}{|c|c|c|c|c|}
\hline $\begin{array}{l}\text { Common cluster } \\
\text { name }\end{array}$ & $\begin{array}{l}\text { Number of } \\
\text { farms }\end{array}$ & $\begin{array}{l}\text { Percentage } \\
\text { of farms }\end{array}$ & $\begin{array}{c}\text { Mean distance } \\
\text { from Addis } \\
\text { Ababa }(\mathrm{km})\end{array}$ & $\begin{array}{c}\text { Mean altitude } \\
\text { (meters above } \\
\text { sea level) }\end{array}$ \\
\hline Debre Zeit & 7 & го.9 & $49 \cdot 6$ & $\mathrm{I}, 870$ \\
\hline Ziway & 6 & $9 \cdot 4$ & $163 \cdot 0$ & $\mathrm{I}, 644$ \\
\hline Sebeta/Alemgena & IO & $15 \cdot 6$ & $25 \cdot 9$ & 2,082 \\
\hline Koka & 3 & $4 \cdot 7$ & $98 \cdot 0$ & I,6I7 \\
\hline Sendafa/Slulta & 5 & $7 \cdot 8$ & $38 \cdot 4$ & 2,228 \\
\hline Holeta/Addis Alem & 20 & $3^{\mathrm{I}} \cdot 3$ & $39 \cdot 3$ & 2,289 \\
\hline Menagesha & 5 & $7 \cdot 8$ & $32 \cdot 8$ & 2,570 \\
\hline Others & 8 & $\mathrm{I} 2 \cdot 5$ & 93.5 & І, 847 \\
\hline Total & 64 & $100 \cdot 0$ & $5^{8 \cdot 9}$ & 2,08I \\
\hline
\end{tabular}

Source: Mulu 2008, Table 2.

TABLE 3

Evolution of floriculture in Ethiopia

\begin{tabular}{|c|c|c|c|c|}
\hline Year & $\begin{array}{c}\text { Number of } \\
\text { farms (growers) }\end{array}$ & $\begin{array}{c}\text { Cultivated } \\
\text { area (ha) }\end{array}$ & $\begin{array}{l}\text { Number of } \\
\text { exported stems }\end{array}$ & $\begin{array}{l}\text { Export value } \\
\text { (UD\$) }\end{array}$ \\
\hline $2001 / 2$ & & & & 305,000 \\
\hline $2002 / 3$ & & & I6,000,000 & $2,900,000$ \\
\hline $2003 / 4$ & & & $32,000,000$ & $5,500,000$ \\
\hline $2004 / 5$ & 30 & I50 & $83,000,000$ & I2,700,000 \\
\hline $2005 / 6$ & 69 & 345 & I86,000,000 & $22,900,000$ \\
\hline $2006 / 7$ & 70 & $80 \mathrm{or} \cdot 6$ & $478,144,926$ & $63,601,220$ \\
\hline
\end{tabular}

Source: primary data MOTI 2007; Ethiopian Customs Authority.

\section{FDI in floriculture and the Dutch role}

The attractiveness of Ethiopia for FDI in floriculture derives from several factors. The natural resource endowment makes the country attractive for growing high-quality flowers in diverse varieties in the highlands and at a range of altitudes. In addition, abundant water, land and proximity to the EU market, with lower transport costs than Kenya, give Ethiopia basic competitive advantages (GRET 2006). In addition to cheap and readily available labour, the external growers mention the low rate of crime and corruption. ${ }^{5}$ Ethiopia is a low-cost production location, similar to Kenya as is shown in Table 4 .

Unit farming costs and unit farm-to-market costs are higher in Ethiopia than Kenya due to higher productivity in the latter. However, this is more 


$$
\text { TA B LE } 4
$$

Benchmarking rose production in Ethiopia and Kenya, 2005/6

\begin{tabular}{|c|c|c|}
\hline Production (farming) cost/ha & $\begin{array}{l}\text { Ethiopia } \\
\$ 63,334\end{array}$ & $\begin{array}{l}\text { Kenya } \\
\$ 81, \mathrm{I} 34\end{array}$ \\
\hline Plants/ha & 65,000 & 80,000 \\
\hline Stems/ha & $\mathrm{I}, 685,000$ & $2,300,000$ \\
\hline Loss rates & $2 \%$ & $5 \%$ \\
\hline Marketable stems/ha & I,65I,000 & $2,180,000$ \\
\hline Farming cost/stem & $\mathrm{US} \phi_{3} \cdot 84$ & $\mathrm{USC}_{4} 3_{50}^{\circ}$ \\
\hline $\begin{array}{l}\text { Post harvest, transport and } \\
\text { marketing }\end{array}$ & $\mathrm{US} \phi$ II $\cdot 66$ & $\mathrm{US} \not 8 \cdot 60$ \\
\hline Total cost/stem & $\mathrm{US} \notin 15.5$ & $\mathrm{US} \notin 12 \cdot 10$ \\
\hline Sales price/stem & $\mathrm{US} \phi 18 \cdot 3$ & $\mathrm{US} \not 14 \cdot 40$ \\
\hline
\end{tabular}

Note: The data refer to running costs only, excluding setup costs.

Source: adapted from GDS 2006.

than compensated for by the higher unit price which Ethiopian flowers fetch, creating a higher profitability in Ethiopia. Moreover, Ethiopia is still in the initial stage of development of the industry, hence the learning curve is yet to rise, potentially resulting in considerable productivity gains. The development of the institutions and infrastructure supporting the chain is equally at an incipient stage. Hence, one may expect future reductions in farming and farm-to-market costs due to productivity increases on the farms, as well as in other segments of the chain.

Export-oriented, high value agricultural products like floriculture are seen by the Ethiopian government as a priority, to implement its 'agriculture-led industrialisation strategy'. A favourable investment climate has been created as the government introduced fiscal incentives including a five-year tax holiday, custom duty exemptions, loss carry forward and remittance of funds (EIA website). The Ethiopian Investment Agency (EIA) serves as a one-stop shop to facilitate investments, and in addition most of the government services related to investment have been reformed, including easy access to land on a leasehold basis.

Last but not least, the Development Bank of Ethiopia (DBE) provides soft loans to the sector. The bank extends credits up to $70 \%$ of the total investment, pledging no other collateral than the project itself. It is difficult to ascertain how important this has been in practice. Comparing data from the EIA with data from DBE, we can conclude that 42 of the 57 investors $(74 \%)$ in the industry registered by the EIA in 2007 had loans from the DBE. According to EIA data, 27 of these investors had a total registered capital of $\mathrm{I} \cdot \mathrm{I}$ billion birr (or $€ 88 \mathrm{~m})$. According to DBE data they 
had approved loans to the value of 623 million birr, or $56 \%$ of registered capital. Of these loans more than $77 \%$ had already been disbursed in 2007 . The list of 27 investors includes 7 Ethiopian investors and 20 nonEthiopians, among them 3 Dutch growers. These Dutch growers had approved loans equal to $46 \%$ of their registered capital. For Dutch growers the DBE finance is less important, due to PSOM and the Sher project (see below).

In addition to the attractiveness of Ethiopia pulling FDI into the country, there have also been push factors stimulating FDI growth in this industry. Globalisation had led to a wider search for alternative investment opportunities, but in particular countries (e.g. Holland) there have been push factors driving investment abroad, due to rising production costs, growth of more profitable alternative crops (e.g. decorative plants and orchids) displacing cut flowers within existing green houses, in combination with limited room for domestic expansion and stricter environmental and land use planning regulations. ${ }^{6}$

Last but not least, rich countries may have bilateral or support multilateral programmes to promote FDI in Ethiopia. The Dutch programme for cooperation in emerging markets (PSOM) is one, and played an important role in stimulating Dutch growers to invest in Ethiopia. PSOM provides grants for up to $60 \%$ of the costs of projects of joint ventures (EVD website). Currently, about eleven purely Dutch FDI and seven Dutch joint ventures are operating in the sector. About eight of these obtained PSOM grants-in-aid. The recipients are either Dutch-Ethiopian joint ventures or include additional partners. Recipients are obliged to operate under internationally accepted quality standards, called Milieu Programma Sierteelt (MPS). MPS is an international certification scheme for floriculture that focuses on creating a socially and environmental friendly working culture at an internationally accepted level (Wijnands 2005). Initiated by The Netherlands in 1995 and later spread to other countries, it monitors chemical use, recycling practice, energy and water use by farms, and also addresses health and occupational safety issues and employment conditions. $^{7}$

Dutch FDI has responded to the attractive conditions of Ethiopian floriculture. In 2003, a group of business people, part of a Dutch trade mission, visited Ethiopia to investigate the investment climate especially in floriculture. However, this had little immediate effect until another visit was organised in 2004 (RNE 2004). This group showed real interest in floriculture, and according to Dutch Embassy representatives in Ethiopia, this was in all likelihood the moment the Dutch started entering the sector. 
An important additional factor that made Ethiopia an attractive location for Dutch flower growers is the operations of Sher Ethiopia Ltd, a subsidiary of Sher Holland BV, the largest rose company in the world. Sher started operations in Ethiopia in June 2005, and builds 'turnkey' projects that are sold to investors on a hire-purchase basis. These projects include building the greenhouses, and technologies needed for production such as irrigation and central spraying units. The 'ready to operate' greenhouses are then rented to investors, and ownership is transferred after 8-9 years. Sher-Ethiopia leased $35^{\circ}$ hectares from the Ethiopian government at Ziway, $\mathrm{I} 63 \mathrm{~km}$ outside Addis Ababa, at an altitude of $\mathrm{I}, 650 \mathrm{~m}$ right next to Lake Ziway (Sher-Holland website). ${ }^{8}$ By June 2007, Sher-Ethiopia operations covered 187 hectares of land, and were expected to reach 207 hectares by June 2008 (MOTI 2007). Sher-Holland BV facilitated in this way the entry of new growers, who do not have to incur high upfront development and investment outlays and the high risks implied in their recuperation. This is an important factor which normally acts as a barrier to overseas investment by small and medium enterprises. Many Dutch flower growers are small and medium-sized family owned firms. Furthermore, Sher-Ethiopia Ltd operates in other parts of the value chain: it imports and distributes inputs for flower production, and provides logistic services, transport, handling and agent services for producers in Holland.

In conclusion, the enormous expansion of the sector since 2004 is due to the combined effect of several factors: Ethiopia is an attractive location due to its natural resource endowment, recently established incentives to attract FDI, the Dutch government programme promoting Dutch-Ethio joint ventures, and the Sher-Holland BV turnkey project. FDI in this industry is not so much about private capital inflows, as it can be financed domestically or indirectly with external loans and grants (e.g. PSOM). Its central significance concerns industry-specific technologies, know-how and entrepreneurship.

THE ETHIOPIAN C U T F O W E R A L U E CHAN

The Ethiopian floriculture value chain, from farm to market, can be divided into farming (pre-harvest), post-harvest, transport and marketing. Pre-harvesting includes activities like selecting the appropriate variety, planting, irrigation and applying the necessary inputs to grow at required quality and to control diseases. Figure I below gives a schematic representation.

As planting the right variety is decisive for success in the sector, breeders are crucial actors in the chain: 'breeders are those who have a unique 


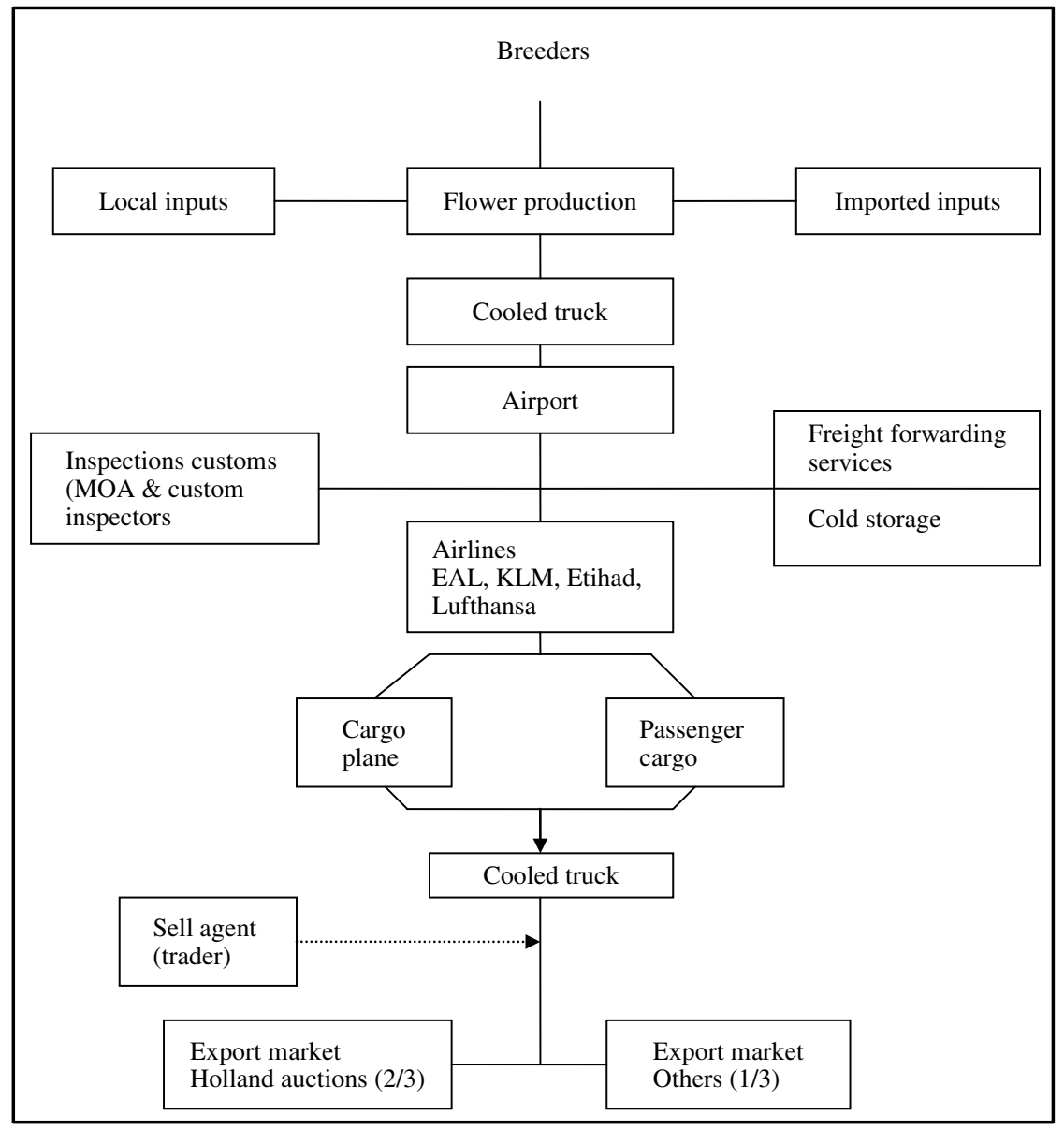

F I G URE I

The Ethiopian cut flower value chain.

right on a variety: the exclusive right to apply for a breeders' right or an exclusive right on a granted breeders' right' (Kras 2004). Accordingly, breeders sell propagation materials for the varieties themselves, or licence others who are usually breeders as well as propagators to sell the protected varieties (ibid.). Domestic producers also buy the variety in this way, ${ }^{9}$ but the breeders sell certain varieties to a select group of flower growers to maximise the protection of their varieties (ibid.; GRET 2006). For soil-grown roses, farming represents only $25 \%$ of the total cost (GDS 2006). 
After harvesting the flowers, each farm undertakes post-harvest activities such as sorting, cutting to the required length, bunching and packing. These post-harvest costs represent less than $2 \%$ of total costs (GDS 2006). Most of the growers have their own cooled processing and packing warehouse and cool trucks. The flowers are inspected at the airport by officers of the Ethiopian Customs Authority (ECA) and the Ministry of Agriculture. Ethiopian Airlines is the industry's principal airfreight carrier, due to a partnership with EHSC (to be discussed later): it transported $70 \%$ of the flowers in 2006/7. KLM, Lufthansa and Etihad transport the remaining share (MOTI 2007).

According to a GDS study, $67 \%$ of Ethiopian flowers are sold at auctions in The Netherlands through VBA or FloraHolland, both of which have their own representatives in Ethiopia to facilitate the marketing. Since Ethiopian Airlines cargo lands in Brussels, Ethiopian producers need to buy logistic services to transport their flowers from Brussels to an agent in Holland. One Dutch company, J. van de Put, provides these logistic services for Ethiopian exporters, and also offers the same services in Ethiopia. ${ }^{10}$

The next step in the value chain is that the flowers arrive (within three days) at a selling agent (trader), who is an important intermediary between domestic firms and the market. The agents' main activities are to unpack and refresh the flowers, make them presentable for the market, and display them at the auction. They also handle trade-related activities with the auctioneers. Dutch companies trade their flowers directly through the company head office or a related subsidiary, via the auctions, or in other ways (direct sales). Transport and marketing represent more than $70 \%$ of total costs (GDS 2006, see Fig. 2). ${ }^{\mathbf{1 1}}$

The Dutch auctions are the largest flower marketplaces in the world, supplying diverse types of flowers from different origins, and with a level of quality which is independently graded by the auctioneers themselves. Similarly, the demand side embraces retailers and importers from different countries (see VBA website). Both suppliers and buyers enjoy considerable benefits from this system. Buyers benefit from the wide range of supply at an assured quality level which also lowers the transaction costs, while suppliers benefit from the transparent pricing system of the auctions. Moreover, the auction offers the opportunity to sell globally and build up image and reputation, and also guarantees the payment to be settled every week (Ammerlaan 2005; Elshof 1996).

The auctions conduct large amounts of transactions very quickly and efficiently with the clock system and 'projected' display information on the type of flower, the producing company, its origin and its quality standard. 


\begin{tabular}{|l|l|l|}
\hline $\begin{array}{l}\text { Farming } \\
24.8 \%\end{array}$ & $\begin{array}{l}\text { Post-harvest } \\
\text { handling } \\
1.7 \%\end{array}$ & $\begin{array}{l}\text { Transport and } \\
\text { marketing } \\
73.5 \%\end{array}$ \\
\hline
\end{tabular}

FIGURE 2

Components of the Ethiopian cut flower value chain.

Source: GDS 2006.

Based on market knowledge, the actual supply and the quality level, the auctioneer announces the highest price to start the auction; then the clock keeps dropping until any buyer stops it to buy at a certain price (Wijnands 2005). Auctioning is a classic case of arm's-length trading. The auction buyer and Ethiopian supplier do not meet, and have hardly any further trade relationship, as was confirmed during interviews.

Other than presenting the flowers in the auction, the intermediary agents also play an important role as a source of market information for Ethiopian producers, and create opportunities to upgrade product quality by giving remarks on every shipment. ${ }^{12}$ Interviews with Ethiopian producers and one of their main agents (DecoFresh Holland) show that agents pay study visits to the farms of their customers in Ethiopia and provide such feedback. Agents can play a role in stabilising the price in the market by withholding certain varieties during days of excess supply, enabling the producers to get a better price. They also search for direct marketing opportunities, and facilitate the process as required. Direct marketing and sales are an alternative to selling at auction. However, only a few domestic growers sell more than $30 \%$ of their product via direct marketing and sales. According to the study sample data, one Ethiopian producer trades $90 \%$ of its flowers via direct marketing, but this is exceptional.

\section{Domestic firms and their positioning in the chain}

Among the Ethiopian entrepreneurs who entered the floriculture industry, one can distinguish three main groups. First, there are a number of wellestablished family-owned businesses which became successful in domestic or import trade, or in growing and processing other agricultural products or even in manufacturing, construction and transport. These were attracted by the high profitability of the new industry, and often hire foreign consultants and production managers to set themselves up in it. A second group consists of diaspora entrepreneurs (often Ethiopian-born but now with another nationality), who returned to Ethiopia after the defeat of the Derg or more recently, and invested in the new sector, sometimes with the 
help of hired foreign consultants. A third group consists of Ethiopians who established their own enterprises, having acquired working experience in the industry in Kenya or elsewhere. These include the entrepreneurs who pioneered the flower industry with summer flowers before switching to roses. In other words, the domestic firms were set up by entrepreneurs who had already been successful in other industries, and have either general competence to set up new businesses, or specific technical competencies in the sector itself. Few have a long-established reputation in the industry, but they do have the competence and experience to run a business in Ethiopia. The educational level of most domestic growers is a first university degree or higher.

All interviewed Ethiopian growers except one have at least one expatriate consultant or production manager. ${ }^{13}$ Expatriate consultants and managers are an important source of learning for the Ethiopian entrepreneurs. One of the domestic producers said: 'thanks to my money, whatever knowledge and technology I need, I can bring from any corner of the world' (interview). Domestic growers also make study tours to The Netherlands and to other African countries, to gain experience and select appropriate technologies.

Product variety, quality and the consistency of the supplier are the major factors required for success in this market. For this, domestic firms rely often on expatriate consultants. In addition they get feedback from their agents (traders) to improve product quality. As a result, domestic producers are strengthening their competitiveness. One of the Dutch flower traders expressed his view about the competence of domestic producers: 'they come with unbelievable quality!' (interview). However, as regards product upgrading, Dutch breeders hold a strong position, as they control access to new varieties. Only a few domestic producers both grow and propagate roses for their own needs.

According to the Development Bank of Ethiopia, the main provider of finance to the sector, domestic growers have a good track record in loan repayment, and in 2007 no Ethiopian producer had accrued arrears. During interviews, auctions representatives also expressed an optimistic view about domestic producers. However, Dutch growers in Ethiopia are far more critical of their Ethiopian counterparts. Two Dutch producers interviewed believe that competition in the sector will crowd out $4 \mathrm{O}^{-} 5 \mathrm{O} \%$ of the domestic producers, due to lack of experience and knowledge in growing flowers. One of them said:

Ethiopian growers think that flower business will make them earn money fast and easy. They don't understand that growing flowers is a way of living or better a lifestyle, and that you have to spend all of your time with the flowers. Local 
producers think they can manage their production by staying in the city and come to their farm once a month ... also they don't want to spend money to hire consultants ...

(interview)

Table 5 provides quantitative insight into the export performance of Ethiopian producers, compared with Dutch and other FDI firms. ${ }^{14}$ During the year $2005 / 6-2006 / 7$, the quantity of flowers exported increased amongst all categories of firms. Ethiopian growers had an average annual growth of $5 \mathrm{I} \cdot 4 \%$, which is below the growth rate of the sector as a whole (163.7\%), and much below the export performance by the Dutch FDI $(584 \%)$. That is the highest growth rate as compared with all other groups of producers, although the Dutch FDI started from a much lower initial level. This indicates that domestic producers need to improve their productivity in order to strengthen their position in the sector. Table 4 also shows that domestic producers reported the highest selling price per stem in 2005/6, and the third highest in 2006/7, next to the Dutch and Dutch joint ventures with other FDI.

According to calculations based on data obtained from MOTI, Ethiopian farms account for $37 \%$ of the land under flower cultivation, and $25 \%$ of the total export volume. FDI uses $49 \%$ of the land under flower cultivation but provides $57 \%$ of the export volume, ${ }^{15}$ showing that on average Ethiopian farms have a much lower productivity than FDI ones. This confirms the critical view expressed above by a Dutch grower.

The European market is the main destination for Ethiopian flowers. In 2003-5, exports to three European countries, The Netherlands, Germany and UK, constituted 9o \% of the total export of Ethiopian flowers (Joosten 2007). Nowadays, new Ethiopian flower destinations are emerging in the Middle East, Japan and USA. Russia and Scandinavian countries are also becoming new destinations.

Ethiopia entered the world flower market after the market changed from being supply-driven to becoming demand-driven (Joosten ibid.). The increasing flower supply from Africa to serve the same market is one of the challenges for Ethiopian flowers growers to build their own niche. Nevertheless, Ethiopia has shown a tremendous growth in market share, and in 2006 was the third largest supplier in one of the Dutch auctions, VBA, next to Kenya and Israel. In the same year, Ethiopian roses fetched

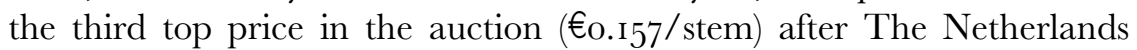

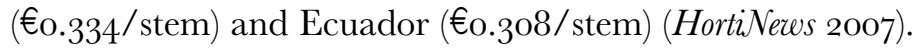

Likewise, one of the main traders of Ethiopian flowers at VBA confirmed that Ethiopian roses are securing the top price in auction and he mentioned that 'you cannot compare Ethiopian flower with 
TABLE 5

Ethiopian floriculture export performance

\begin{tabular}{|c|c|c|c|c|c|c|c|c|}
\hline \multirow[b]{2}{*}{ Producers by nationality } & \multicolumn{4}{|c|}{ Year 2005/2006 } & \multicolumn{4}{|c|}{ Year 2006/2007 } \\
\hline & $\begin{array}{c}\text { No. of } \\
\text { exporter }\end{array}$ & $\begin{array}{l}\text { Quantity } \\
\text { in stems }\end{array}$ & $\begin{array}{l}\text { Value } \\
\text { (US\$) }\end{array}$ & $\begin{array}{c}\text { Average } \\
\text { price/stem } \\
\text { (US\$) }\end{array}$ & $\begin{array}{c}\text { No. of } \\
\text { exporter }\end{array}$ & $\begin{array}{l}\text { Quantity } \\
\text { in stems }\end{array}$ & $\begin{array}{l}\text { Value } \\
\text { (US\$) }\end{array}$ & $\begin{array}{c}\text { Average } \\
\text { price/stem } \\
\text { (US\$) }\end{array}$ \\
\hline Ethiopian & 2I & $74,766,217$ & $6,178,369$ & I2. IO & $3^{8}$ & II $3,248,184$ & I3,087,223 & 8.65 \\
\hline Dutch (FDI) & 4 & $26,171,522$ & $2,29 \mathrm{I}, \mathrm{I} 47$ & II $\cdot 42$ & II & I79,023,697 & $\mathrm{I} 7,533, \mathrm{I} 25$ & $\mathrm{IO} \cdot 2 \mathrm{I}$ \\
\hline Joint Ethio \& Dutch & 4 & $8,78 \mathrm{I}, \mathrm{I} 38$ & I,093,938 & $8 \cdot 03$ & 5 & $4^{1}, 152,670$ & $5,408,788$ & $7 \cdot 6 \mathrm{I}$ \\
\hline Joint Ethio \& others & 4 & $\mathrm{I} 5,770, \mathrm{I}_{32}$ & $\mathrm{I}, 746,502$ & $9 \cdot 03$ & 4 & $21,869,052$ & $3,156,154$ & $6 \cdot 93$ \\
\hline Joint Dutch \& others (FDI) & 2 & I,912,635 & $\mathrm{I} 76,717$ & $10 \cdot 82$ & 2 & I0,030,435 & $\mathrm{I}, \mathrm{I} 46,800$ & 8.75 \\
\hline Others + unknown & I4 & $53,9 \mathrm{I} 5,33^{\mathrm{I}}$ & I0,476,585 & $5 \cdot 15$ & 26 & І І $2,820,888$ & $23,269,130$ & $4 \cdot 85$ \\
\hline Total & 49 & เ81,316,975 & $21,963,25^{8}$ & $8 \cdot 26$ & 86 & $478,144,926$ & $63,601,220$ & $7 \cdot 5^{2}$ \\
\hline
\end{tabular}

Note: Average price/stem is f.o.b. Addis Ababa Airport.

Source: Calculations based on data obtained from the Ethiopian Customs Authority (ECA). 
Kenya ... The moment Ethiopian flowers appear in the auction the price lifts up above the average immediately...' (interview). An international VBA import officer in Addis Ababa echoed this view. More recently, Ethiopian flower producers have begun entering the major retail supermarket chains, such as Morrisons of UK. This has a great contribution towards diversifying the market (MET website).

\section{Interactions between Dutch FDI and Ethiopian firms}

The Ethiopian floriculture industry consists of domestic and foreign investors who have different levels of knowledge and experience in different parts of the chain. Dutch firms are dominant players in the chain of Ethiopian floriculture. Prior to arriving in Ethiopia, they had built up a trademark and reputation in the international market. Domestic producers have limited exposure and knowledge, and can potentially gain from the spillover of experiences from Dutch FDI. Spillover effects can happen if the two interact with each other, if direct linkages occur, and/or if the two start cooperating on particular joint activities. Below we will examine the degree to which these are happening.

At present, the level of linkage and cooperation seems to be incipient, albeit growing. There is limited crowding in of domestic input suppliers and other service providers. Both Ethiopian and Dutch growers who were interviewed confirm that their cooperation rarely passes the stage of noncore activities like borrowing input from neighbours in case of temporary shortage, exchanging information, buying non-strategic inputs jointly, and participating in social activities.

The Dutch have strong relationships amongst themselves. They visit each other's farms and receive feedback; they discuss better ways of doing business, the market and local conditions. Only a few domestic producers have such relationships between themselves or with Dutch growers. According to some domestic growers this may be due to the existing business culture of the country, which was unused to cooperation and collective learning before. They also felt that trust had yet to be established, so as to facilitate cooperation in core activities in the sector. During the interview one of the domestic producers said: 'you know we Ethiopians have problem ... we're stuck with traditional ways of doing business ... no cooperation between competitors. We think that we only compete with the producers around us forgetting the global competition out there which can throw out all of us from the sector ...' (interview).

The Dutch do not attend producer meetings regularly because they do not think that they gain much, except for dealing with local conditions and 
paper work. Most domestic producers therefore think that the Dutch growers are highly reserved and unwilling to forge relationships with local growers. Such perceptions can hinder learning exchange between domestic producers and Dutch FDI. Notwithstanding, many expect relationships to improve as the sector gets more established and producers get to know each other better. For instance, one of the pioneers of Dutch FDI in the sector said that 'cooperation with Ethiopians at first was difficult, but once you have reached a partnership, it is a solid one' (HortiNewes 2007).

In this regard, the growers under the Sher-Ethiopia turnkey project are in a better position to cooperate, and are already undertaking more joint activities than producers located elsewhere. For instance, they jointly hire cool trucks, and visit each others' farms more frequently. They set common standards for wage payment to minimise turnover of workers, which used to be a problem before. Furthermore, they regularly meet with Sher-Ethiopia's managing director to discuss issues such as the development of their business and social security. This creates better opportunities for domestic and Dutch growers to get to know each other and to work together. One of the Ethiopian producers under SherEthiopia stated that there is a certain diffusion of best practices from Dutch FDI: 'I learned from my foreign neighbours how to improve productivity and to spend more time in my farm, more than 40 hours a week' (interview).

Dutch firms dominate breeding of roses in the world. Five out of the six companies, which together are responsible for $70-80 \%$ of world breeding output, are Dutch-owned. These firms work closely with Dutch growers and this gives Dutch FDI in Ethiopia privileged access to best varieties, which further boosts their competitive advantage in the sector over Ethiopian as well as other growers. Breeders play an important role in the market. For instance, they release specific varieties for a specific period of time for selected clients, so that the price of those varieties can remain higher. Some Ethiopian producers complained during interviews about their difficulties in getting access to these top varieties.

\section{The role of Dutch development cooperation in the development of the Ethiopian cut flower chain}

The development of supporting institutions has made considerable advances and these have facilitated the rapid expansion of the industry. This subsection briefly notes its main advances and examines the role of Dutch development cooperation in the process. 
The Ethiopian Horticulture Producers and Exporters Association (EHPEA), created in 2002, is an important actor and vehicle for the implementation of development cooperation programmes. Currently it has seventy members, of whom more than $90 \%$ are flower producers. EHPEA represents the interests of the growers vis-à-vis the government, and plays an important role in building the competitiveness of the sector. It provides the following services to its members (EHPEA website): representing its members nationally as well as internationally; lobbying with government to promote the interest of growers; providing market information and facilitating new entrants; building up partnerships with national and international organisations, and initiating projects for development of the sector; organising and implementing capacity building in the sector; organising events and exhibitions; and promoting the sector.

In 2006 the Dutch Ministry of Agriculture, Nature and Food Security (LNV) opened an office at the Netherlands embassy, and assigned an agriculture counsellor to promote bi-lateral relations with special focus on the floriculture sector. In the same year, the Ethiopia-Netherlands Horticulture Partnership (ENHP) was signed to promote the development of the sector and to enhance an enabling environment through publicprivate partnership. The ENHP incorporates the following (Helder \& De Jager 2006): capacity building programme for the floriculture sector; creation of a code of practice for the sector; capacity building of a Phytosanitary Unit; provision of market and sector information services; action plan for Integrated Pest Management; decision support system for selecting new production areas; study tours to different countries (Ethiopian delegations to Zambia, Kenya and The Netherlands); and investment guidance manual for floriculture.

Following the partnership programme, support funds have been made available within the International Research Programme of the LNV Ministry. Activities listed in the partnership are based on the findings of the Ethiopian horticulture development strategy study undertaken by Wageningen University and Research Centre (WUR), implementation of which is underway.

The growers' association and The Netherlands embassy work together to implement the activities with regard to ENHP. Currently, the association is implementing the Code of Practice to enhance the sustainability of the sector and to generate well-trained staff. This provides a performance standard at three levels, which should be followed at least by the members of the association. Meeting the requirements under the Code of Practice enables the producers to meet the international MPS standards already noted. 
Experienced expatriate specialists in vocational horticulture training have developed and coordinated the training, along with four domestic experts who were sponsored under the partnership by the Dutch government. This training programme is planned to be placed in a new vocational horticultural training centre, recently approved under ENHP for Jimma University to strengthen its contribution to horticulture, and more specifically floriculture sector development. Jimma University is a local university for agriculture research, which will become the main source of human resource development and of agricultural research and specialist services. The creation of this local knowledge centre will therefore play an important role in the future consolidation of the value chain.

Last but not least, there is the Dutch programme for emerging markets, PSOM. Besides its role in promoting the expansion of farm production through joint ventures, this has facilitated the establishment of supporting services. The Ethiopian Perishables Logistics Company received the grant and established cool truck and storage for perishable flowers and vegetables from farm to their destination in Europe. PSOM grant aided a horticulture supplier company called Horticoop, which provides essential laboratory services for water and soil analysis (RNE no. IO, 2007).

DEVELOPMENTAL IMPACTS OF THE FLORICULTURE INDUSTRY IN E T H I O P I A

The following brief discussion focuses on the sector's impact regarding the creation of employment, foreign exchange earnings, forward and backward linkages, and joint activities between flower growers to enhance the collective efficiency of the sector.

The floriculture sector of Ethiopia is an important generator of employment. Based on data from the Ministry of Trade and Industry, we calculated that the sector had generated 15,200 permanent and 8,800 casual jobs by June 2007. A 2008 survey (Mulu 2008) puts the figure even higher at 25,000 permanent workers. Most workers $(60-70 \%)$ are women who, according to the growers interviewed, are preferred as they are more committed and work neatly. In addition, according to MOTI data, more than I0,00o labourers were engaged in construction of greenhouses as of March 2006. Due to the fact that most flower farms are located in rural areas, they become an important source of livelihood for many local people, and inhabitants are able to diversify their sources of income and escape from severe poverty. Most of the 
workers are unskilled. They earn US\$0.78-I.67 per day. In the case of the Sher-Ethiopia project, the producers fixed the minimum wage at \$I.I per day. Nevertheless, the workers are not yet unionised to protect their own rights.

The floriculture sector also generates foreign exchange. Table 3 shows the tremendous growth in the past five years (MOTI 2007). According to the National Bank of Ethiopia (NBE), Ethiopia does not fully benefit, as the selling price reported by exporters is below the price which Ethiopian flowers actually fetch in export markets. As a result, the country loses significant amounts of foreign exchange revenue (ibid.). In 2006 the NBE issued a directive which required the exporters' association to report on auction prices offered for Ethiopian flowers. This would enable the NBE to verify prices declared by exporters as part of their export permits. In 2007 the NBE issued directive FXD/32/2007, which required all commercial banks to reject flower export permit applications with a price below US\&ı ı per stem. ${ }^{16}$

There are some backward linkages in non-core inputs, but local content in the sector remains very low. It is highly dependent on imported inputs to grow flowers. According to data obtained during fieldwork, about $80 \%$ of the required input is imported and only $20 \%$ is produced domestically; this mainly involves packing materials. ${ }^{17}$ According to MOTI data collected in 2006, more than ten domestic firms supply locally produced packing materials, and several importers of other inputs have emerged, as have other service providers in logistics and a soil analysis laboratory. In the case of forward linkages, a few domestic firms are trying to sell directly to buyers and are creating retail shops locally in exclusive restaurants, supermarkets and main streets.

In 2004 the Ethio-Horti-Share Company (EHSC) was established by a small group of both domestic and foreign producers, as a profit making company to provide services for all interested producers, and undertake activities related to cargo transport and the import of inputs. Through the EHSC, growers jointly import fertilisers in bulk. In addition it has developed a mutually beneficial partnership with Ethiopian Airlines through which growers jointly rent cargo planes. EHSG receives the growers' production and export plans in advance to plan and rent cargo space. During the low season for Ethiopian flowers, the company sells excess cargo capacity to other interested parties, especially vegetable exporters, thereby reducing transport costs for its flower growers. Thanks to the same partnership Ethiopian Airlines has secured a major share of the flower transport market. 
TABLE 6

Development direction of Ethiopian floriculture sector

\begin{tabular}{|c|c|c|c|}
\hline \multirow{2}{*}{ Component } & \multirow{2}{*}{ Indicator } & \multicolumn{2}{|c|}{ Towards } \\
\hline & & Endogenisation & Enclave formation \\
\hline \multirow[t]{10}{*}{ Production } & $\begin{array}{l}\text { Concentration of domestic } \\
\text { firms in the sector } \\
\text { - quantitatively }\end{array}$ & $\begin{array}{l}\text { Growing number of firms and } \\
\text { of production area ... }\end{array}$ & but FDI dominates \\
\hline & $\begin{array}{l}\text { - qualitatively (level of } \\
\text { local ownership and } \\
\text { control) }\end{array}$ & $\begin{array}{l}\text { Land ownership, Association } \\
\text { (EHPEA), Airfreight } \\
\text { services (ET) }\end{array}$ & $\begin{array}{l}\text { informal networks of } \\
\text { Dutch growers }\end{array}$ \\
\hline & $\begin{array}{l}\text { Competencies and } \\
\text { attitudes of domestic } \\
\text { entrepreneurs }\end{array}$ & & $\begin{array}{l}\text { Domestic entrepreneurs } \\
\text { with hands off attitude; } \\
\text { low qualifications } \\
\text { and attracted by quick } \\
\text { profits only }\end{array}$ \\
\hline & $\begin{array}{l}\text { Cooperation between } \\
\text { domestic firms and FDI }\end{array}$ & Incipient but ... & $\begin{array}{l}\text { in non-core activities } \\
\text { only }\end{array}$ \\
\hline & $\begin{array}{l}\text { Transfer of knowledge } \\
\text { and best practices }\end{array}$ & $\begin{array}{l}\text { Directly through joint } \\
\text { ventures; indirectly } \\
\text { via labour mobility }\end{array}$ & \\
\hline & $\begin{array}{l}\text { Performance of domestic } \\
\text { firms (productivity, } \\
\text { quality and price)- }\end{array}$ & $\begin{array}{l}\text { Higher quality and price for } \\
\text { domestic firms compared } \\
\text { with competitors in the } \\
\text { Region ... }\end{array}$ & $\begin{array}{l}\text { but much lower quality, } \\
\text { price and productivity } \\
\text { than FDI }\end{array}$ \\
\hline & Forward linkages & Incipient direct sales & little through FDI \\
\hline & Backward linkages & Incipient but growing, & $\begin{array}{l}\text { but limited to non-core } \\
\text { inputs and some services }\end{array}$ \\
\hline & $\begin{array}{l}\text { Access to varieties for } \\
\text { domestic firms and FDI }\end{array}$ & & $\begin{array}{l}\text { Restrictive practices of } \\
\text { Dutch breeders }\end{array}$ \\
\hline & $\begin{array}{l}\text { Upgrading opportunities } \\
\text { for domestic firms }\end{array}$ & $\begin{array}{l}\text { Incipient but growing via traders, } \\
\text { expatriate consultants and } \\
\text { sector institutions }\end{array}$ & \\
\hline \multirow[t]{2}{*}{ Trading } & $\begin{array}{l}\text { FDI control over } \\
\text { trading/ traders/trade } \\
\text { infrastructure }\end{array}$ & $\begin{array}{l}\text { Dutch cooperative flower } \\
\text { auctions are an open trade } \\
\text { channel for domestic firms }\end{array}$ & $\begin{array}{l}\text { Intra-firm trading } \\
\text { by FDI }\end{array}$ \\
\hline & Market segmentation & & $\begin{array}{l}\text { Restrictive practices by } \\
\text { breeders result in some } \\
\text { market segmentation }\end{array}$ \\
\hline \multirow[t]{2}{*}{$\begin{array}{l}\text { Sectoral } \\
\text { development }\end{array}$} & $\begin{array}{l}\text { Policies by Ethiopian } \\
\text { Government - FDI } \\
\text { policy }\end{array}$ & $\begin{array}{l}\text { Financial incentives open to } \\
\text { all firms (domestic loans } \\
\text { against projects; } \\
\text { loan guarantees) }\end{array}$ & \\
\hline & $\begin{array}{l}\text { International cooperation } \\
\text { by Dutch government } \\
\text { - PSOM } \\
\text { - ENHP } \\
\text { - University } \\
\text { cooperation }\end{array}$ & $\begin{array}{l}\text { Diffusion of MPS standards } \\
\text { to domestic firms }\end{array}$ & $\begin{array}{l}\text { PSOM open only to } \\
\text { Dutch firms (but } \\
\text { results in joint } \\
\text { ventures between } \\
\text { Dutch and Ethiopian } \\
\text { firms) }\end{array}$ \\
\hline
\end{tabular}


DEVELOPMENT DIRECTION OF THE ETHIOPIAN CUT FLOWER VALUE GHAIN AND THE TRIPLE ROLE OF THE DUTGH

In previous sections, we have described and assessed the main aspects of the floriculture value chain, and looked at the role of FDI and domestic firms and other supporting actors and their activities. We can now synthesise its development direction, applying the assessment criteria summarised in Table $\mathrm{I}$ in order to answer the question concerning the development direction, towards endogenisation or enclave formation.

In addition we have examined the three major roles of Dutch actors in the Ethiopian floriculture value chain, i.e. production, trading and institutional sector development. The Dutch are dominant actors in all three roles, and we can attempt to answer the question to what extent these roles have been reinforcing each other, and to the extent that they do, whether this is only to the benefit of Dutch FDI. Findings are summarised in Table 6.

The assessment shows that a number of criteria score positively for endogenisation: it may be emerging but, it should be stressed, from incipient and very low levels. On balance, there are positive signs but global quality competition remains a serious challenge to Ethiopian firms and supporting institutions. It should also be stressed that endogenisation is a process: continuous improvement in all the criteria is crucial to sustain progress. It is also a two-sided process: does FDI enlist local firms and share technological capabilities, and are local firms ready to acquire these? Are local institutions supporting such efforts?

The role of FDI as a source of private capital inflow is much less important than expected. We found that a considerable part of the investment of both Ethiopian and foreign flower investors is financed from DBE loans. In addition Dutch investors can obtain investment grants from their own government if they invest in joint ventures with Ethiopian firms. Last but not least, the Sher project permits investors to obtain ready to operate greenhouses on a hire-purchase basis, eliminating the need for upfront investment in fixed assets. Many Dutch growers have entered such agreements with Sher.

FDI is a source of technological know-how, especially through joint ventures and very limited knowledge spillovers. Cooperation between Ethiopian and FDI growers is incipient and limited to non-core but nevertheless important logistic and procurement services. The interaction between Dutch and Ethiopian growers is however limited (with the exception of the Sher project), the number of joint ventures is relatively small, and inter-firm cooperation is restricted to the same non-core activities (notably farm to airport logistics and input procurement). Dutch 
growers in Ethiopia do not directly provide market access to Ethiopian growers, but the Dutch cooperative auctions have internationalised, and provide crucial market access. At the same time, Dutch breeders adopt restricted practices in licencing and distributing new varieties, giving priority to established international clients over new local entrants.

Looking at the other side of endogenisation, the technological capacities of Ethiopian entrepreneurs are weak. Ethiopian entrepreneurs rely on expatriate experts contracted from abroad (India, Kenya), who assist them in acquiring productive capacities. While the entrepreneurs have general competencies about doing business in Ethiopia, their industry-specific competencies and attitudes may not be strong enough to ensure the endogenisation process, though there are important exceptions. In terms of Lall's classification of technological capacities (Lall \& Narula 2004), Ethiopian firms have mostly acquired production capacities, often with the help of foreign consultants, while investment capacities may not be very strong, as evidenced by imitative behaviour.

The creation of indigenous technological effort centres on the creation of supporting institutions. International cooperation plays a significant role, especially with regard to the diffusion of MPS standards and the creation of a knowledge centre at a university. This has yet to materialise, and it would take a number of years of capacity building for it to develop a reputation in the industry. In future this would make it possible to build advanced competitive advantages (Porter I985).

In conclusion, FDI does not share core capabilities, nor do domestic firms active in the industry seem eager to acquire these, as evidenced by their hands-off attitude. International cooperation contributed to create a potential for endogenisation, especially in the medium term, but it would need a new breed of domestic entrepreneurs to take up the challenge.

The next question is whether the triple roles of the Dutch reinforce each other, serving only the interest of Dutch FDI. From the analysis presented it is important to conclude that Dutch FDI and Dutch trading auctions, which trade Ethiopian flowers, are independent entities. Auctions, which have evolved historically through cooperative action by Dutch growers to protect themselves from undue trader influence, are now performing the same function for Ethiopian growers. Dutch FDI commonly resort to intra-firm trading and trade directly with interested parties, so that the two indeed operate in parallel. Importantly, Dutch FDI is, above all, nonfinancial in origin. Many Dutch firms acquire their production facilities on a hire-purchase basis and can raise domestic finance. Dutch growers are medium-sized firms with a strong commitment to the industry, and may be less mobile than large TNGs. This may constitute an advantage for 
improved relationships in the future. With regard to the third role, Dutch development cooperation, it would be fair to conclude that this tends to benefit the whole sector and specifically Ethiopian firms. The introduction and diffusion of the MPS standard and the creation of an R\&D and HRD centre all contribute to strengthen production capabilities. This is not the case for PSOM, whose grants are designed to benefit Dutch FDI, though PSOM aims to create joint ventures which are potentially an important channel for knowledge transfer.

In this paper, we have examined the evolution of the Ethiopian cut flower industry and raised two questions. The first refers to the long-term benefits for Ethiopia of an industry dominated by FDI. Will the new industry become an enclave, or will it be accompanied by a process of building local capabilities, a process which we denominate endogenisation? As the cut flower industry in Ethiopia is characterised by a dominant role of Dutch foreign investors, Dutch trade auctions, which dominate the export trade, and the Dutch development cooperation, which plays an important role in the development of the sector, a second question is to what extent this triple role of the Dutch contributes to endogenisation or to enclave formation.

As regards the first question we argue that endogenisation is a two-way process. It depends on the one hand on the degree to which FDI has an interest to enter into relationships with domestic firms and share technologies. On the other hand, it depends on domestic firms and their interest and ability to 'take up' such opportunities and on the creation of supporting institutions and infrastructures to make this 'take-up' possible. The latter rests to a large extent with government while also collective action among firms in the industry can be important here.

On the basis of the indicators summed up in Table 5, we conclude that endogenisation is taking place to a limited extent and at a very incipient stage. However, Dutch FDI has little direct relationship with domestic farms in the industry and hence has little interest to share technologies. There is joint collective action on non-core activities, notably (air and land) transport, which constitutes the largest cost component. Dutch cooperative flower auctions are an open and vital trade channel, giving Ethiopian flower growers access to international markets. The Ethiopian government has developed a pro-active policy to promote the industry, giving tax and excise duty rebates, allowing full profit repatriation, making land and finance available at low cost, and with the assistance of Dutch bilateral cooperation it is actively promoting trade standards and creation of supporting knowledge institutions to train skilled staff. The main 
challenge is Ethiopian entrepreneurship. Many are attracted by the high growth and profitability of the industry, and have general competence to run a successful business in Ethiopia (by no means a sinecure), but lack the technical competence to meet growing competition in the industry, which is central to creating dynamic competitive advantage.

As regards the second question, we conclude that the triple role of the Dutch in Ethiopian floriculture goes beyond enclave formation, and is helping to create a win-win situation for both countries. Ethiopia benefits, since the Dutch help to establish a new export industry which generates considerable employment and foreign exchange, but at the same time the Dutch benefit from the three roles: along with the prosperity for the Dutch FDI, the Dutch are building a sustainable, high-quality, supply base for their world-leading flower auctions.

\section{NOTES}

I. The main varieties of summer flowers that are produced in Ethiopia for export purpose include hypercium, erigrinium, gypsophilia and carnation.

2. Following interviews held in Addis during August 2007, a representative sample was developed for the study that embraced Dutch FDI and domestic firms in the floriculture sector of Ethiopia. Twenty-six domestic firms and thirteen Dutch FDI have been engaged in the sector. From those, eight domestic producers and four Dutch FDI were selected based on year of establishment, size of firm and accessibility. During fieldwork we only managed to interview two Dutch FDI due to the difficulties in reaching them; domestic producers were interviewed as planned. Next to interviewing, visits were paid to two Ethiopian and one Dutch farm. With the guidance of results from the interviews, the most important firm trading most Ethiopian flowers produced by domestic firms was interviewed. The main marketplace for Ethiopian flowers, VBA, the Dutch auction in Aalsmeer, was visited. Concerned individuals and institutions were interviewed in both Ethiopia and The Netherlands, including: a representative of VBA in Ethiopia; the Development Bank of Ethiopia (DBE), which is the main finance provider to the sector; the special advisor for the sector in the Ministry of Trade and Industry (MOTI) of Ethiopia; the National Bank of Ethiopia; the producers' association of the sector; and Ethio-Horti-Share Company (EHSC). To collect data related to the role of the Dutch regarding development cooperation and other aspects in the sector, interviews were conducted with the agriculture counsellor assigned in the Dutch embassy in Ethiopia, the PSOM officer for Ethiopia, the former Dutch vice-ambassador in Ethiopia, the PUM officer for Ethiopia, and an expatriate training specialist.

3. This is a semi-ripe flower stem which is exported before it is fully grown.

4. According to the strategic development plan of the sector, the production coverage is predicted to reach 2,000 hectares in 2009/Io (Joosten 2007; MOTI 2007).

5. Interview, Dutch grower.

6. The relative importance of these 'push factors' could not be established within this research.

7. Local environmentalists claim that PSOM's approach towards processing applications in relation to corporate social responsibilities does not consult local stakeholders, and that there is no transparency as to how monitoring and evaluation is taking place (IUCN NL \& Both ENDS 2007). The PSOM officer responded in an interview that the programme closely monitors and evaluates the above aspects: 'we know that there are watchdogs, they always bark anyway' (interview). He added that local concerned entities do not have clear rules to be followed. PSOM found it difficult to work with local communities due to language and other practical barriers.

8. The complete details of the agreement between the government of Ethiopia and Sher-Holland could not be established.

9. According to Mulu 2008, $96 \%$ of domestic firms buy licensed material and pay royalties. 
Io. The transport company in Ethiopia was established with a grant from PSOM as a joint venture of J. van de Put, two domestic companies, and another Dutch company (FloraHolland). The joint venture gives logistics services for perishables. The domestic producers who participate in the SherEthiopia project use the logistic services in The Netherlands provided by Sher-Holland.

II. A more recent survey (Mulu 2008) estimates transport and marketing to be a much smaller percentage of total costs $(40 \cdot 5 \%)$.

I2. According to Mulu 2008, the auctioneer contact is the most important source of marketing information for $54 \%$ of the domestic firms; only $20 \%$ of the foreign firms operating in Ethiopia depend on auctions as their major source of marketing information.

I3. The exception is a grower who has several years of experience in the Kenyan flower sector.

I4. The Customs Authority data presented in Table 4 is not fully consistent with the data obtained from MOTI. For example, according to MOTI the number of exporters in 2007 was 64 , whereas Table 4 shows 86; some of these companies and individuals appear irregularly in the list of exporters of ECA. It would seem that the number of exporters in $2006 / 7$ (86) is inflated. This may be due to double counting of single companies with different names.

I5. The balance is constituted by joint ventures.

I6. This concerns the price f.o.b. Addis Ababa, that is auction price less transport and marketing fees.

I7. According to a 2008 survey (Mulu 2008), there has been increased local sourcing. For example, local sourcing of planting material rose from I6. I \% in 2005 to $50 \cdot 3 \%$ in 2007 . In the same period local sourcing rose from $9 \cdot 7 \%$ to $30 \cdot 0 \%$ for fertiliser and from $12 \cdot 4 \%$ to $33 \cdot 6 \%$ for chemicals.

\section{R E F E R E N C E S}

Ammerlaan, F. 2005. 'Chances for the Ethiopian floriculture: competitive position and markets for the Ethiopian rose production industry', Master's thesis, University of Amsterdam.

Best, M. 1990. The New Competition: institutions of industrial restructuring. Cambridge: Polity Press.

Centrum Bevordering Importen uit Ontwikkelingslanden (CBI ). 2006. 'CBI market survey: the cutflowers and foliage market in the Netherlands', Rotterdam: CBI.

Dicken, P. 2003. Global Shift: reshaping the global economic map in the 2Ist century. London: Sage.

Dolan, G. \& J. Humphrey. 200o. 'Governance and trade in fresh vegetables: the impact of UK supermarkets on the African horticulture industry', Journal of Development Studies 37, 2: 147-76.

Elshof, P. I996. 'The Dutch flower sector: structure, trends and employment', ILO working paper I20. Geneva: ILO, available at: http://www.ilo.org/public/english/dialogue/sector/papers/ flrsect/flrsect4.htm, accessed I3.II.2007.

Ethiopia National Strategic Team (ENST). 2006. 'Growing out of poverty: a strategic direction in the agricultural sector of Ethiopia', paper presented for International Trade Center. Geneva, ITC, available at: http://www.intracen.org/wedf/ef20o6/global-debate/Country-Team-Papers/ Ethiopia_Paper.pdf, accessed 4.II.2007.

Gereffi, G. 1994. 'The organization of commodity chains', in G. Gereffi \& M. Korzeniewicz, eds. Commodity Chains and Global Capitalism. London: Praeger, 92-121.

Gereffi, G., J. Humphrey, R. Kaplinsky \& T. Sturgeon. 200I. 'Introduction: globalization, value chains and development', IDS Bulletin 32, 3: I-IO.

Gibbon, P. 200I. 'Upgrading primary production: a global commodity chain approach', World Development 29, 2: $345^{-63}$.

Global Development Solutions (GDS). 2006. 'An overview of the integrated value chain analysis of selected strategic sectors in Ethiopia', power point presented for the government of Ethiopia and the World Bank, Addis Ababa, 23 May.

Görg, H. \& E. Strobl. 2005. 'Foreign direct investment and local economic development: beyond productivity spillover', in T. Moran, E. Graham \& M. Blomstrom, eds. Does Foreign Direct Investment Promote Development? Washington, DC: Institute for International Economics, Center for Global Development, ${ }^{137}-55$.

Groupe de Recherche et d'Échanges Technologiques (GRET). 2006. 'Horticulture in Eastern and Southern Africa (ESA)', Sustainability impact assessment (SIA) of the EU-ACP economic partnership agreements, Phase 3, available at: www.sia-acp.org/acp/.../20070516-Rapport-SIAHorticulture.pdf, accessed 29.I0.2007.

Helder, J. \& A. de Jager. 2006. 'Ethiopian-Netherlands Horticulture Partnership', report on agenda setting mission, 29 May-2 June. 
Helmsing, A. H. J. 200I. 'Externalities, learning and governance: new perspectives on local economic development', Development and Change 32, 2: 277-308.

Helmsing, A. H. J. 2005. 'Local economic development in Africa: new theory and policy practices', in Tegegne Gebre Egziabher \& A. H. J. Helmsing, eds. 2005. Local Economic Development in Africa: enterprises, communities and local government. Maastricht: Shaker Publishing, I8-6o.

Helmsing, A. H. J. 2007. 'Promotion of local economic development: globalisation of roses and local economic development in Ethiopia', lecture handout, The Hague: Institute of Social Studies.

Hojman, D. 1983. 'From Mexican plantations to Chilean mines: the theoretical and empirical relevance of enclave theories in contemporary Latin America', working paper 3, Centre of Latin American Studies, Liverpool University.

IUCN NL \& Both ENDS. 2007. 'The flower industry in Kenya and Ethiopia', Trade matters series, available at: www.iucn.nl/sbeos/doc/file.php?nid $=4826$, accessed I5.II.2007.

Joosten, F. 2007. 'Development strategy for the export-oriented horticulture in Ethiopia', Wageningen: Wageningen University and Research Centre.

Kaplinsky, R. 2000. 'Globalization and unequalisation: what can be learned from global value chain analysis?', Fournal of Development Studies 37, 2: II7-46.

Kras, J. 2004. 'Breeders' right', Floraculture International. Heiloo: Ball publishing, I-2.

Lall, S. \& R. Narula. 2004. 'Foreign direct investment and its role in economic development: do we need a new agenda?', European Fournal of Development Research I6, 3: 447-64.

Ministry of Trade and Industry (MOTI), Government of Ethiopia. 2007. 'Budget plan for 2007/2008: the export production of floriculture', Addis Ababa: MOTI (Amharic text).

Mulu Gebreeyesus. 2008. 'Micro evidence on the development of the cut-flower industry in Ethiopia', power point presentation to the Initiative for Policy Dialog Task force on Africa, IO-II July 2008, Addis Ababa: Ethiopian Development Research Institute, available at: http://wwwo.gsb. columbia.edu/ipd/pub/cut_flower_Mulu.ppt\#2, accessed Io.9.2009.

Poh, C. 2006. 'Transplanted or endogenized? FDI and industrial upgrading in developing countries: case study of Indonesia', PhD thesis, The Hague: Institute of Social Studies.

Porter, M. E. 1985. Competitive Advantage: creating and sustaining superior performance. New York: The Free Press.

UNCTAD. 2005. Economic Development in Africa: rethinking the role of foreign direct investment. New York \& Geneva: United Nations publications, sales no. E.05.II.D.I2.

Weisskoff, R. \& E. Wolff. I977. 'Linkages and leakages: industrial tracking in an enclave economy', Economic Development and Cultural Change 25, 4: 607-28.

Wijnands, J. 2005. Sustainable International Networks in the Flower Industry: bridging empirical findings and theoretical approaches. The Hague: LIE.

World Bank. 2004. 'Opportunities and challenges for developing high-value agricultural exports in Ethiopia', report I draft, available at: http://siteresources.worldbank.org/INTETHIOPIA/ Resources/PREM/OppandChallengesHighValueExports.pdf, accessed II.I0.2007.

\section{Newsletters and Web sources}

EHPEA website, available at: http://www.ehpea.org.et/contactus\% $\%$ 20I.htm, accessed 9.II.2007.

EIA website, available at: http://www.investethiopia.org/ethiopia/incentives.aspx, accessed 8.9.2007.

EVD website, Programme for cooperation with emerging markets, available at: www.evd.nl/psom, accessed 2.II.2007.

HortiNewes. 2007. Newsletter, March 2007.

Middle East Times (MET) website 'UK supermarket to stock Ethiopian roses', available at: http:// www.metimes.com/storyview.php?StoryID=200602 I4-074637-3999r, accessed 9.II.2007.

Ministry of Economic Affairs website, The Hague, available at: www.evd.nl.

Royal Netherlands Embassy (RNE). 2004. Trade and Business Nerwsletter No. 6, Addis Ababa: RNE.

RNE. 2007. Trade and Business Neresletter No. Io, Addis Ababa: RNE.

Sher-Holland website, available at: http://www.sher.nl/en/ethiopie.html, accessed 9.II.2007.

VBA website, available at: http://www.vba.nl/, accessed 8.II.2007. 